\begin{tabular}{|c|c|c|}
\hline \multirow[b]{2}{*}{ CEI I ENT } & Int.J.Curr.Microbiol.App.Sci (2021) 10(08): 305-311 & \\
\hline & $\begin{array}{l}\text { International Journal of Current Microbiology and Applied Sciences } \\
\text { ISSN: 2319-7706 Volume } 10 \text { Number } 08 \mathbf{( 2 0 2 1 )} \\
\text { Journal homepage: http://www.ijcmas.com }\end{array}$ & 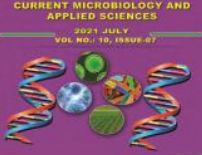 \\
\hline PUBLISHERS & & www.ijcmas.com \\
\hline
\end{tabular}

\title{
Antifungal Activity of Medicinal Plants Collected from Servarayan Hills, Eastern Ghats, against Dermatophytic Fungi
}

\author{
K. Arivalagan and M. Prakash* \\ Research Department of Microbiology, Kanchi Shri Krishna College of Arts and Science, \\ Kilambi, Kanchipuram, Tamil Nadu 631551, India \\ *Corresponding author
}

\section{A B S T R A C T}

Keywords

Antifungal activity,

Crude extracts,

Medicinal plants,

Dermal fungi,

Servarayan hills

Article Info

Accepted:

15 July 2021

Available Online:

10 August 2021
Antimicrobial chemotherapy is ever growing research around the globe due to emerging new and drug resistant microorganisms. In the present study, different concentrations ethanolic leaf extracts of six different plant species, Aristolochia indica (Aristolochiaceae), Coleus strobilifer (Lamiaceae), Lepidagathis cristata (Acanthaceae), Rhinacanthus nasutus (Acanthaceae), Spatholobus parviflorus (Fabaceae), and Tarenna asiatica (Rubiacee), collected from various localities in Servarayan hill ranges, Salem district, south India were tested against the dermatophytic fungal pathogens, Trichophyton mentegrophytes and Candida albicans using disc diffusion technique. Fluconazole $(10 \mu \mathrm{g})$ was used as standard antibiotic for comparison which showed 2.3 and $2.5 \mathrm{~cm}$ zone of inhibition respectively against Trichophyton mentegrophytes and Candida albicans respectively. At $1000 \mathrm{ppm}$ concentration, the leaf extracts of Lepidagathis cristata showed a maximum of $2.1 \mathrm{~cm}$ zone of inhibition against both Trichophyton mentegrophytes and Candida albicans followed by Coleus strobilifer and Tarenna asiatica. The results reveal that the ethanolic leaf extracts of Lepidagathis cristata could be further investigated for the phytochemical component responsible for antifungal activity.

\section{Introduction}

The medicinal herbs have long been used as natural antimicrobial agents where the useful parts range from root, bark, stem, leaves, fruits, flowers, tubers, etc. (Khan et al., 2013). In search of various medicinal ailments, researchers are seriously searching for the medicinal plants used by the traditional healers. Several medicinal plants have been screened for their antimicrobial activity across the countries to identify potential medicinal plants with reference to the development of drug resistance among microorganisms (Nascimento et al., 2000; Vigneshwari et al., 2014). Dermatomycosis or ringworm infection by fungi is a serious problem in humans and animals. Trichophyton mentegrophytes, a 
dermal fungus known to be prevalent above the rate of $26 \%$ in Asia which has been frighteningly increased in the last few years (Gnat et al., 2020). Candidiasis, is a fungal skin and membrane associated disease mostly develop by Candida albicans infection almost $70-80 \%$ of the cases (Aaron, 2020). These fungi are considered as emerging source of skin diseases in humans that developed resistance to drugs (Fattahi et al., 2021; Martinez-Rossi et al., 2018), requiring the development of antifungal drugs urgently.

The Servarayan hills of southern Eastern Ghats, Salem district, South India is known to harbor enormous potential medicinal plants used by local residents for curing several diseases in human beings as well as in cattle (Rekha et al., 2020; Udayan et al., 2006; Usha et al., 2016). Parthiban and co-workers reported that a total of forty eight medicinal plants of included in forty five genera and twenty nine families practiced by the local populace of Yercaud, a part of Servarayan Hills (Parthipan et al., 2011). About 21 different ethno-veterinary medicinal plants of 16 families have been explored to cure various diseases in cattle (Usha et al., 2016). Recently, Rekha et al., (2020) reported forty various ethnomedicinal plant species belonging to thirty eight genera and twenty five families used by Malayali tribes residing at Yercaud hills, Tamil Nadu. Ethanolic extracts of six different plants namely, Cryptolepis buchanani, Gymnema sylvestre, Hemidesmus indicus, Secamone emetica, Leptadenia reticulata and Wattakaka volubilis belonging to the family Asclepiadaceae collected from Servarayan hills have been tested for antimicrobial activity (Nagaraj et al., 2018). The results also revealed that the ethanolic extract of Leptadenia reticulata showed moderate antimicrobial activity. However, the knowledge on the antifungal efficacy of several medicinal plants against dermatophytes is very limited. Hence, in the present study, six different medicinal plants that are largely available with known medicinal properties in Servarayan Hills of south India have been selected for the present study. In this study, the leaves of the selected medicinal plants have been subjected to ethanolic extraction and the crude extracts thus obtained were screened for two species of dermatophytic fungi, Trichophyton mentagrophytes, and Candida albicans.

\section{Materials and Methods}

\section{Collection of medicinal plants}

Based on the availability and medicinal knowledge, six species of medicinal plants, Aristolochia indica L., Coleus strobilifer (Roxb.) A.J.Paton, Lepidagathis cristata Willd., Rhinacanthus nasutus (L.) Kurz, Spatholobus parviflorus (DC.) Kuntze and Tarenna asiatica (L.) Kuntze ex K.Schum. were selected and the leaves of each plant were collected from different localities in Servarayan Hills, Salem district, Tamil Nadu, India, for the present study (Table 1; Fig. 1). Initially, the identification of plants and their current botanical names were confirmed with eflora of India Google group database (https://sites.google.com/site/efloraofindia/ho me). Various parts of the plants were packed in plastic covers and transported to the laboratory for further processing. The dust adhering to the outer surface of plant parts were removed and kept for air drying under shade for one week. Then the plant materials were individually powdered and kept in air tight containers until extraction.

\section{Preparation crude extract}

The powdered leaf materials were separately subjected to cold extraction using ethanol as solvent according to the method described by Kalpana and Prakash (2015). After 48 h immersion of powdered leaf materials with 
intermittent stirring, the extract was filtered through Whatman No. 1 filter paper followed by centrifugation to remove plant powder, if any. The crude extracts thus obtained were condensed by rotary vacuum evaporator and the final greasy crude extracts were collected and stored under refrigeration prior to antifungal studies. A known quantity of each crude extract was made into different concentrations, 62.5, 125, 250, 500, and 1000 ppm using distilled water with few drops of Triton-X100, and finally used for studying antifungal activity.

\section{Antifungal activity of crude extracts}

For testing antifungal activity, two different dermatophytic fungi namely, Trichophyton mentagrophytes, and Candida albicans maintained in PDA slants, originally procured from Institute of Microbial Technology (IMTECH) were activated using PDA broth. The Petri plates of $100 \mathrm{~mm}$ diameter with PDA media were swabbed with broth culture of test fungus in separate plates with sterile swab. Filter paper discs impregnated with different concentrations of plant extracts were placed in environmental safety cabinet, in triplicates for each extract. Fluconazole (10 $\mu \mathrm{g}$ ) was used as standard antibiotic along with control (without extract, $0 \mathrm{ppm}$ ). The plates were then incubated at $37^{\circ} \mathrm{C}$ for $3-5$ days and the zone of inhibition (ZI) was recorded.

\section{Results and Discussion}

Though there have been many new and novel drugs developed against fungal diseases, due to the lack of reasons pertaining to low impact and production, in addition to the development of drug resistance by pathogenic fungi diverted the researchers towards the medicinal plants with active phytochemical ingredients. The utilization of medicinal plants traditionally used in folk medicine certainly forms an alternative remedy for fungal infections, owing to the multifunctional phytochemical active ingredients with less toxic substances, economical, easily reachable and low side effects (Monteiro and Santos, 2019). In the present study, the ethanolic extracts of leaves of six different medicinal plant species collected from Servarayan hills, South India were tested against two species of dermatophytes. The results showed that the highest concentration of ethanolic leaf extracts of medicinal plants, Aristolochia indica, Coleus strobilifer, Lepidagathis cristata, Rhinacanthus nasutus, Spatholobus parviflorus and Tarenna asiatica at $1000 \mathrm{ppm}$ were with $1.1,1.8,2.1,1.2,1.3$ and $1.3 \mathrm{~cm}$ zone of inhibition against the dermatophytic fungi, Trichophyton mentegrophytes (Fig. 2). Overall, the inhibition of fungal organisms used in the study was dependent on the concentration gradient of the extracts used. Against, Trichophyton mentegrophytes, the lowest test concentration of $62.5 \mathrm{ppm}$ showed minimal zone formation ( $0.9 \mathrm{~cm}$ zone) where it was $125 \mathrm{ppm}$ for Lepidagathis cristata (0.9 $\mathrm{cm}), 500 \mathrm{ppm}$ for Aristolochia indica $(0.9 \mathrm{~cm}$ zone) and 1000 ppm for Rhinacanthus nasutus $(1.2 \mathrm{~cm}$ zone). A maximum inhibition zone of $2.1 \mathrm{~cm}$ was recorded in the ethanolic leaf extract of Lapidagathis cristata against Candida albicans and 1000 ppm concentration followed by $1.8 \mathrm{~cm}$ for Tarenna asiatica $>1.5$ $\mathrm{cm}$ for Coleus strobilifer $>1.4 \mathrm{~cm}$ for Aristolochia indica $>1.1 \mathrm{~cm}$ for Rhinacanthus nasutus $>1.0 \mathrm{~cm}$ for Spatholobus parviflorus (Fig. 3).

The medicinal plants are the vital source of cure for several illnesses in humans caused by pathogenic microorganisms. For case in a point, Amaranthus spinosus extracts are reported as a good antifungal source against Candida albicans, Saccharomyces cerevisia, Aspergillus niger, Fusarium oxysporium and Aspergillus flavus (Jadhav and Biradar, 2016). 
Table.1 Plants and the parts used for the preparation of extract.

\begin{tabular}{|c|c|c|}
\hline Botanical name & Common name & Family \\
\hline Aristolochia indica L. & Indian birthwort & Aristolochiaceae \\
\hline Coleus strobilifer (Roxb.) A.J.Paton & Thick leaved lavender & Lamiaceae \\
\hline Lepidagathis cristata Willd. & Crested Lepidagathis & Acanthaceae \\
\hline Rhinacanthus nasutus (L.) Kurz, & Snake jasmine & Acanthaceae \\
\hline $\begin{array}{c}\text { Spatholobus parviflorus } \text { (DC.) Kuntze } \\
\text { Tarenna asiatica } \text { (L.) Kuntze ex } \\
\text { K.Schum. }\end{array}$ & Palas-climber & Fabaceae \\
\hline
\end{tabular}

Fig.1 Plants selected for the present study. (A) Aristolochia indica, (B) Coleus strobilifer, (C) Lepidagathis cristata, (D) Rhinacanthus nasutus, (E) Spatholobus parviflorus and (F) Tarenna asiatica.

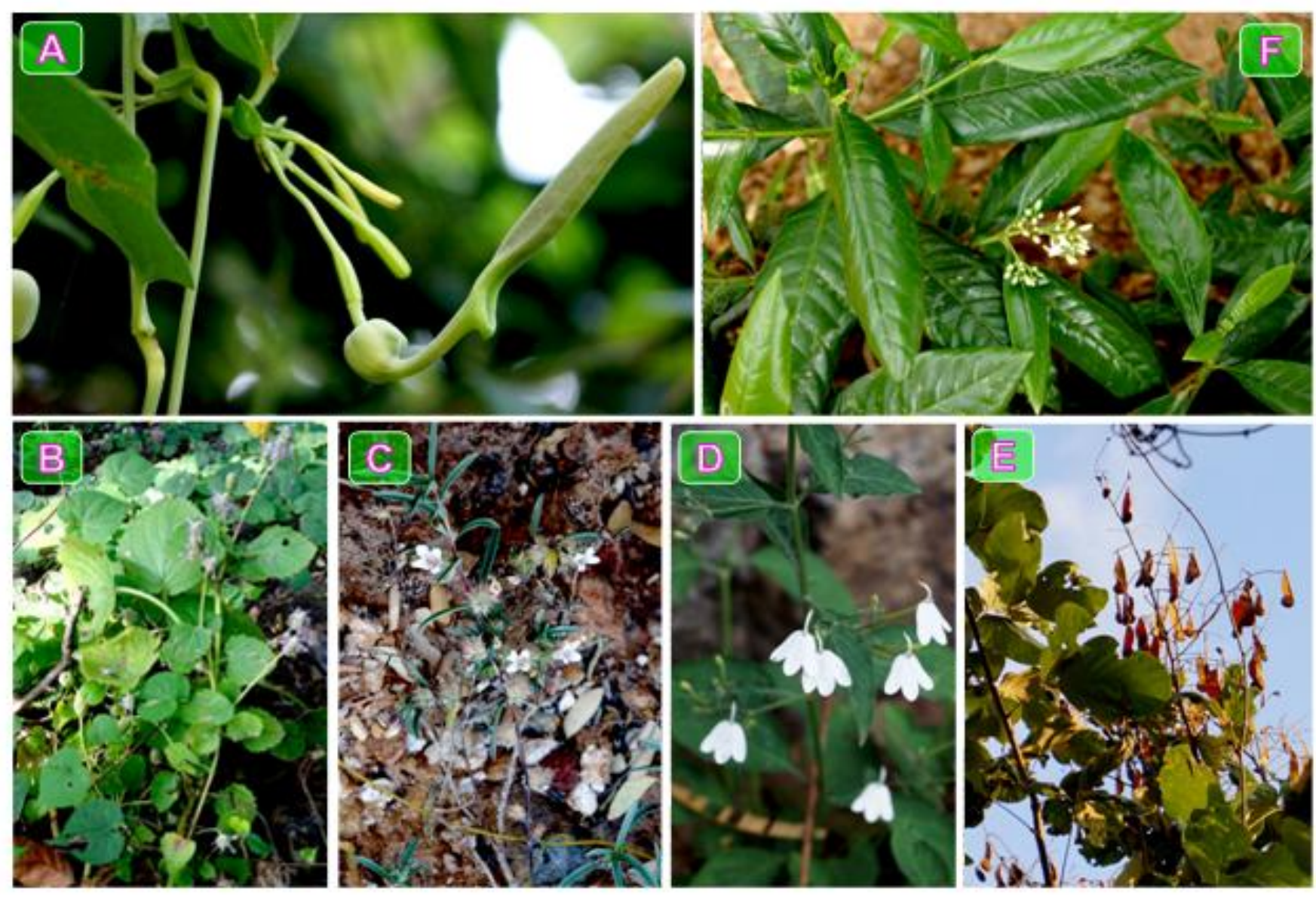


Fig.2 Antifungal activities of ethanolic leaf extracts of selected medicinal plants against Trichophyton metagrophytes. Std - Standard antibiotic, Fluconazole (10 $\mu \mathrm{g})$. Values expressed are mean \pm standard deviation (error bars).

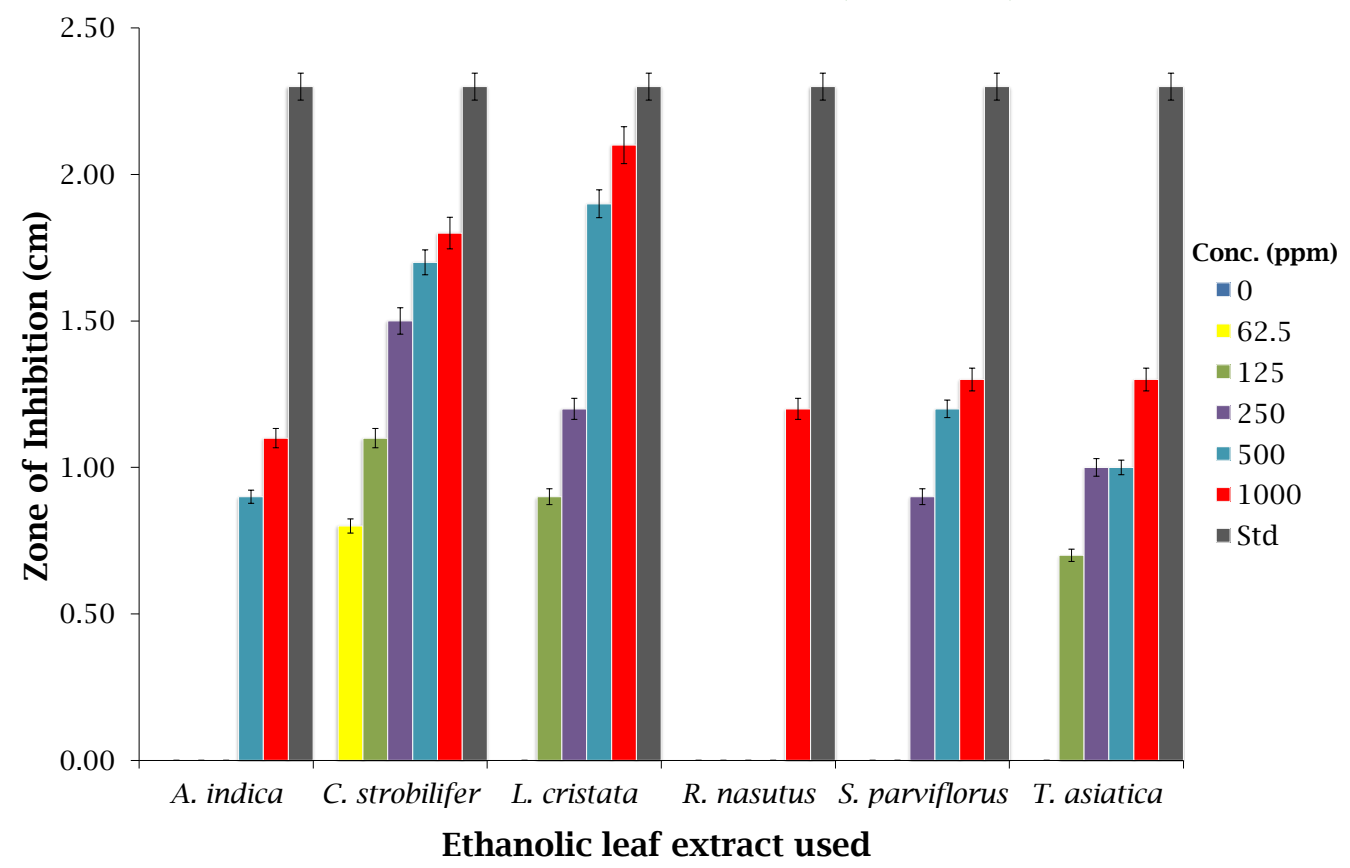

Fig.3 Antifungal activities of ethanolic leaf extracts of selected medicinal plants against Candida albicans. Std - Standard antibiotic, Fluconazole $(10 \mu \mathrm{g})$. Values expressed are mean \pm standard deviation (error bars).

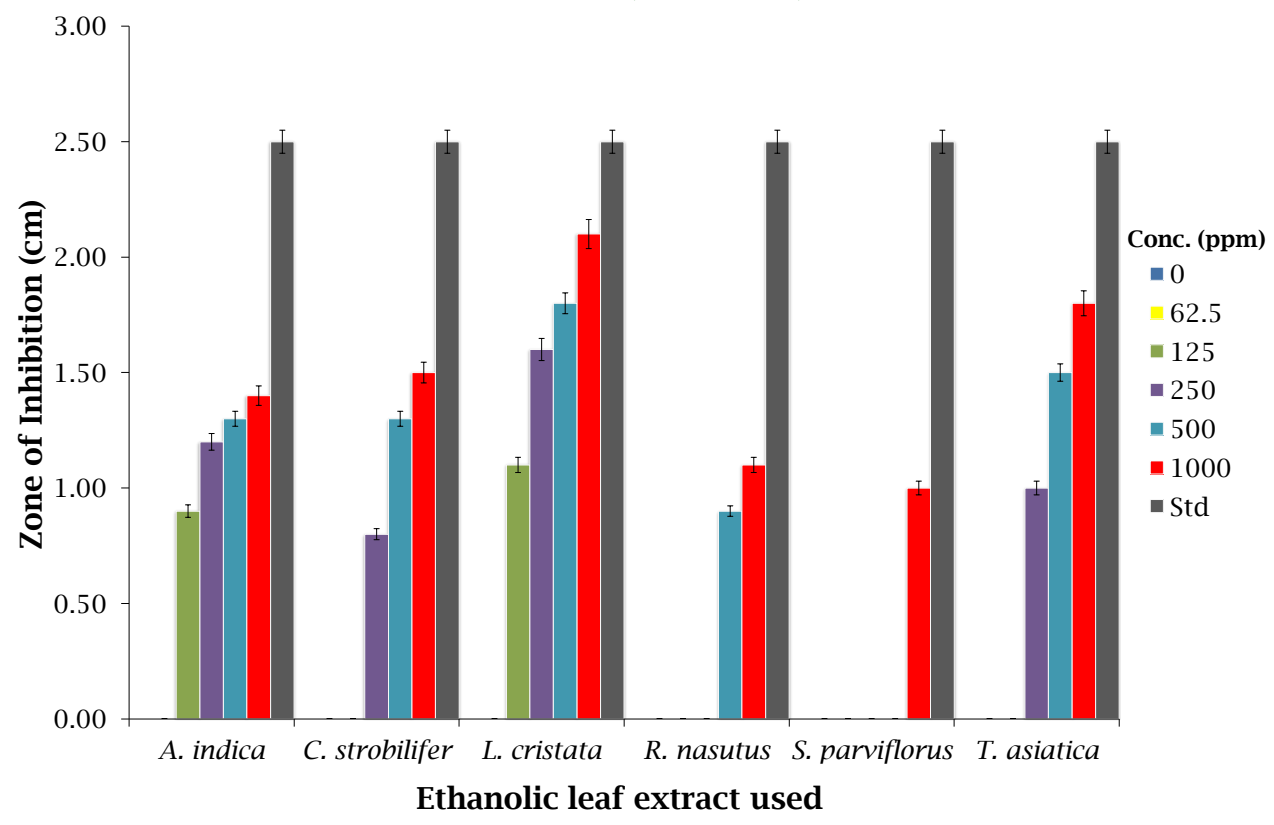

The reports reveal that curcumin (200 fumigatus in comparison to synthetic $\mathrm{mg}$ /disc) has retained the highest antifungal derivatives used as antifungal agents (Gitika $e t$ activity on Aspergillus flavus and Aspergillus al., 2019). The ethyl acetate extract of Piper 
nigrum showed excellent antimicrobial activity against dandruff causing fungi (Gitika et al., 2019).

The extract of the medicinal plant, Coleus exhibited antibacterial activity against several fungal organisms with a minimal inhibitory concentration range of $0.146-15.63 \mathrm{mg} / \mathrm{ml}$ (Tarh and Iroegbu, 2017).

A study conducted on antifungal activity of Syzygium jambolanum, Cassia siamea, Odina wodier, Momordica charantia, Melia azedarach against a large number Candida strains revealed the antifungal activity at 100 $\mathrm{mg} / \mathrm{ml}$ for Syzygium jambolanum and Cassia siamea (Prabhakar et al., 2008). The main mechanism of antifungal activity exerted by medicinal plants is due to the presence of a wide range of phytochemical compounds.

The effective plant species reported in the present study requires further investigation on the phytochemical compounds present in the extract to elucidate the exact active principle.

The findings of the current study clearly indicate that the antimicrobial activity of medicinal plants is variable depending on the concentration and the test microorganism.

Considering the antifungal activity of ethanolic leaf extracts tested, Lepidagathis cristata showed promising results that could be used for developing antifungal drug after further investigations with the specific phytochemical compound responsible through various advanced studies.

\section{References}

Aaron, D. M., 2020. Candidiasis (Mucocutaneous) - Dermatologic Disorders - MSD Manual Professional Edition [WWW Document]. MSD Man. Prof. Versions. URL https://www.msdmanuals.com/en-

in/professional/dermatologic-

disorders/fungal-skin-

infections/candidiasis-mucocutaneous

Fattahi, A., Shirvani, F., Ayatollahi, A., Rezaei-Matehkolaei, A., Badali, H., Lotfali, E., R, G., Z, P., A, F., 2021. Multidrug-resistant Trichophyton mentagrophytes genotype VIII in an Iranian family with generalized dermatophytosis: report of four cases and review of literature. Int. J. Dermatol. 60, 686-692.

Gitika, A., Mishra, R., Kumar Panda, S., Mishra, C., Sahoo, P. R., 2019. Evaluation of antifungal activity of curcumin against Aspergillus flavus. Int. J. Curr. Microbiol. App. Sci 8, 2323-2329.

Gnat, S., Łagowski, D., Nowakiewicz, A., Osińska, M., Kopiński, Ł., 2020. Population differentiation, antifungal susceptibility, and host range of Trichophyton mentagrophytes isolates causing recalcitrant infections in humans and animals. Eur. J. Clin. Microbiol. Infect. Dis. 39, 2099-2113.

Jadhav, V., Biradar, S. D., 2016. Evaluation of antifungal activity of Amaranthus spinosus L. (Amaranthaceae). Int. J. Curr. Microbiol. App. Sci 5, 38-43.

Kalpana, B., Prakash, M., 2015. Antibacterial activity of Capparis sepiaria L. (Capparidaceae) leaves and fruits. Int. J. Curr. Microbiol. App. Sci 4, 10071012.

Khan, U. A., Rahman, H., Niaz, Z., Qasim, M., Khan, J., Tayyaba, Rehman, B., 2013. Antibacterial activity of some medicinal plants against selected human pathogenic bacteria. Eur. J. Microbiol. Immunol. (Bp). 3, 272-274. Martinez-Rossi, N. M., Bitencourt, T. A., Peres, N. T. A., Lang, E. A. S., Gomes, E. V., Quaresemin, N. R., Martins, M. P., Lopes, L., Rossi, A., 2018. 
Dermatophyte Resistance to Antifungal Drugs: Mechanisms and Prospectus. Front. Microbiol. 9. https://doi.org/10.3389/

FMICB.2018.01108

Monteiro, C. de A., Santos, J. R. A. dos, 2019. Phytochemicals and Their Antifungal Potential against Pathogenic Yeasts, in: Phytochemicals in Human Health. IntechOpen.

https://doi.org/10.5772/INTECHOPEN .87302

Nagaraj, R., Ranjithkumar, G., Prakash, M., Karmegam, N., 2018. Antimicrobial activity of ethnomedicinally important Asclepiads from Shervaroyan Hills, Southern Eastern Ghats. Int. J. Curr. Res. Biosci. Plant Biol. 5, 86-94.

Nascimento, G. G. F., Locatelli, J., Freitas, P. C., Silva, G. L., 2000. Antibacterial activity of plant extracts and phytochemicals on antibiotic-resistant bacteria. Brazilian J. Microbiol. 31, 247-256.

Parthipan, M., Aravindhan, V., Rajendran, A., 2011. Medico - botanical study of Yercaud hills in the eastern Ghats of Tamil Nadu, India. Anc. Sci. Life 30, 104.

Prabhakar, K., Kumar, L. S., Rajendran, S., Chandrasekaran, M., Bhaskar, K., Khan, A.K.S., 2008. Antifungal activity of plant extracts against Candida species from oral lesions. Indian J. Pharm. Sci. 70, 801.

Rekha, R., Nirubama, K., Duraisamy, M., 2020. Potential of ethnobotanical medicinal plants used by Malayali tribes in Yercaud hills, Eastern ghats of Tamil Nadu, India. J. Appl. Nat. Sci. 12, 560-567.

Tarh, J. E., Iroegbu, C. U., 2017. Evaluation of anti-fungal activity of Coleus species extracts. Int. J. Curr. Res. Biosci. Plant Biol. 4, 2349-8080.

Udayan, P. S., George, S., Tushar, K. V., Balachandran, I., 2006. Medicinal plants used by the Malayali tribe of Servarayan hills, Yercad, Salem district, Tamil nadu, India. Zoos Print 21, 2223-2224.

Usha, S., Rajasekaran, C., Siva, R., 2016. Ethnoveterinary medicine of the Shervaroy Hills of Eastern Ghats, India as alternative medicine for animals. J. Tradit. Complement. Med. 6, 118-125.

Vigneshwari, C., Nagaraj, R., Karmegam, N., 2014. Synergistic anti-Staphylococcus aureus (methicillin resistant) activity of ethnomedicinal plants from Shevaroy Hills (Eastern Ghats), South India. Int. J. Curr. Res. Biosci. Plant Biol. 1, 51-59.

\section{How to cite this article:}

Arivalagan, K. and Prakash, M. 2021. Antifungal Activity of Medicinal Plants Collected from Servarayan Hills, Eastern Ghats, against Dermatophytic Fungi. Int.J.Curr.Microbiol.App.Sci. 10(08): 305-311. doi: https://doi.org/10.20546/ijcmas.2021.1008.035 